\title{
Stability Indicating HPLC Method for Quantification of Solifenacin Succinate \& Tamsulosin Hydrochloride along with Its Impurities in Tablet Dosage Form
}

\section{Hari Kishan Reddy Ganthi1,2, Raveendra Reddy $\mathbf{P}^{1 *}$, Young Jun Park ${ }^{2}$, Hanimi Reddy Bapatu², So Jin Park ${ }^{2}$, Woo Hyong Cho}

${ }^{1}$ Department of Chemistry, Sri Krishnadevaraya University, Anantapur, India

${ }^{2}$ Celltrion Chemical Research Institute, Youngin, South Korea

Email: ^drhanimi@gmail.com

How to cite this paper: Ganthi, H.K.R., Reddy P, R., Park, Y.J., Bapatu, H.R., Park, S.J. and Cho, W.H. (2016) Stability Indicating HPLC Method for Quantification of Solifenacin Succinate \& Tamsulosin Hydrochloride along with Its Impurities in Tablet Dosage Form. American Journal o1 Analytical Chemistry, 7, 840-862.

http://dx.doi.org/10.4236/ajac.2016.711073

Received: August 1, 2016

Accepted: November 27, 2016

Published: November 30, 2016

Copyright $\odot 2016$ by authors and Scientific Research Publishing Inc. This work is licensed under the Creative Commons Attribution International License (CC BY 4.0).

http://creativecommons.org/licenses/by/4.0/

\begin{abstract}
A novel stability-indicating RP-HPLC method was developed and validated for simultaneous determination of Solifenacin Succinate \& Tamsulosin Hydrochloride and its impurities in tablet dosage form. The method was developed using L1 column with gradient using the mobile phase consist of solvent- $\mathrm{A}(\mathrm{pH}=6.6$, phosphate buffer $+0.5 \%$ Triethylamine) and solvent-B (90\% Acetonitrile). The eluted compounds were monitored at $225 \mathrm{~nm}$. Solifenacin Succinate \& Tamsulosin Hydrochloride was subjected to oxidative, acid, base, hydrolytic, thermal and photolytic stress conditions. The developed method was validated as per ICH guidelines with respect to specificity, linearity, limit of detection, limit of quantitation, accuracy, precision and robustness. The limit of quantification results was ranged from $0.135-0.221 \mu \mathrm{g} / \mathrm{mL}$ for Solifenacin Succinate impurities and $0.043-0.090 \mu \mathrm{g} / \mathrm{mL}$ for Tamsulosin Hydrochloride impurities. This method is suitable for the estimation of impurities and assay of Solifenacin Succinate \& Tamsulosin Hydrochloride in tablets dosage form.
\end{abstract}

\section{Keywords}

Solifenacin, Tamsulosin, RP-HPLC, Impurities, Method Validation

\section{Introduction}

Solifenacin Succinate \& Tamsulosin Hydrochloride is available with the brand name of "VESOMNI" in the form of modified-release tablets with the dosage strength $6 \mathrm{mg} / 0.4$ $\mathrm{mg}$. Therapeutic indication of this brand is to treat moderate to severe storage symp- 
toms like urgency, increased micturition frequency and voiding symptoms associated with benign prostatic hyperplasia (BPH) in men who are not adequately responding to treatment with monotherapy [1] [2] [3].

Solifenacin succinate (SOL) is a competitive muscarinic acetylcholine receptor antagonist. Chemically, Solifenacin succinate is butanedioic acid (3R)-1-azabicyclo [2.2.2] octan-3-yl(1S)-1-phenyl-1,2,3,4-tetrahydroisoquinoline-2-carboxylate having an empirical formula of $\mathrm{C}_{27} \mathrm{H}_{32} \mathrm{~N}_{2} \mathrm{O}_{6}$ and molecular weight of $480.5528 \mathrm{gms} / \mathrm{mol}$.

Tamsulosin (TAM) is a selective antagonist at $\alpha 1-\mathrm{A}$ and $\alpha 1-\mathrm{B}$ adrenoceptors in the prostate, prostatic capsule, prostatic urethra and bladder neck. It brings about relaxation of prostatic and urethral smooth muscle. Chemically Tamsulosin is 5-[(2R)-2-\{[2(2-ethoxyphenoxy)ethyl]amino\}propyl]-2-methoxybenzene-1-sulfonamide having an empirical formula of $\mathrm{C}_{20} \mathrm{H}_{28} \mathrm{~N}_{2} \mathrm{O}_{5} \mathrm{~S}$ and molecular weight of $408.512 \mathrm{gms} / \mathrm{mol}$.

Monograph for SOL drug substance is available only in European Pharmacopoeia [4]. TAM drug substance and capsules monograph are available in USP [5] [6] [7]. Literature survey reveals that HPLC, Semi micro HPLC, UPLC, UV and LC-MS/MS methods for SOS [8]-[15] and HPLC, LC-ESI-MS/MS and spectrophotometric methods [16]-[23] for TAM are available. However no method was reported for the estimation of SOL \& TAM and their impurities by HPLC in any of combination dosage forms. Israel et al. [24] reported a method for the estimation of SOL \& TAM, but not for the quantification of impurities.

The objective of this article is to present a stability-indicating method to estimate SOL \& TAM and its related compounds. In the present work, a simple, fast and precise liquid chromatographic method was developed for the determination of SOL \& TAM and its impurities. The chemical structures of SOL \& TAM and their impurities are presented in Figure 1.

\section{Experimental}

\subsection{Chemicals and Reagents}

The purity of all chemicals used was above $99 \%$. And standards of SOL (100\%), TAM (100\%) and their impurities namely SOL-1 (99.93\%), SOL-2 (100\%), SOL-3 (99.9\%), TAM-1 (93.68\%), TAM-2 (100\%), TAM-3 (92\%) and TAM-4 (89.4\%) were supplied by Celltrion, South Korea. The HPLC gradient grade acetonitrile from J T Baker, and analytical grade ortho phosphoric acid, monobasic potassium phosphate and triethylamine were purchased from Sigma Aldrich. High purity water was prepared by using Milli-Q Plus water purification system (Millipore USA). Standard and Test samples were prepared in Acetonitrile and Milli-Q water in the ratio of 50:50 v/v as diluent.

\subsection{Equipment}

Analysis was performed with an Agilent 1260 HPLC (Germany). HPLC system equipped with a quaternary solvent manager, sample manager, column-heating compartment, and Photodiode array detector. The output signal was monitored and processed using Chemstation software. Grant digital water bath was used for hydrolysis studies. Ther- 


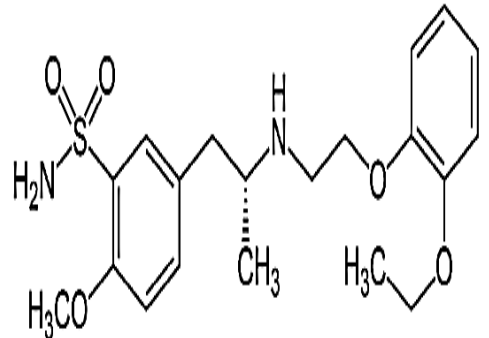

$5-[(2 R)-2-\{[2-(2-$

ethoxyphenoxy) ethyl] amino\} propyl]-2-methoxybenzene-1sulfonamide

\section{A. Tamsulosin (TAM)}<smiles>c1ccc([C@H]2NCCc3ccccc32)cc1</smiles>

(1S)-1-phenyl-1, 2, 3, 4tetrahydro isoquinoline

D. SOL-2 /S-IQL

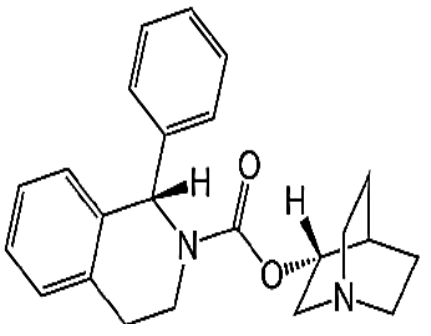

butanedioic acid (3R)-1azabicyclo[2.2.2]octan-3-yl (1S)-1phenyl-1,2,3,4tetrahydroisoquinoline-2-carboxylate

B. Solifenacin (SOL)<smiles>O=CN1C[C@@H]2CC[C@H](C2)[C@H]1OC(=O)N1CCc2ccccc2C1c1ccccc1</smiles>

(1S)-3,4-dihydro-1-phenyl-2-(1H)isoquinolinecarboxylic acid (3R)-1azabicyclo[2.2.2] oct-3-yl ester $\mathrm{N}$-oxide C. SOL-1 /N-oxide<smiles>CCOC(=O)N1CCc2ccccc2[C@H]1c1ccccc1</smiles>

(S)-1,2,3,4-tetrahydro-1phenylisoquinoline-2carboxylic acid ethyl ester E. SOL-3 /S-IQL-CARB

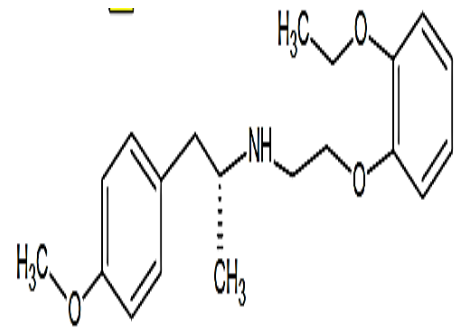

(2R)-N-[2-(2-ethoxy phenoxy) ethyl]-1-(4-methoxy phenyl) propan-2-amine hydrochloride G. TAM-2 (EP-H)<smiles>CCOc1ccccc1OCCN(CCOc1ccccc1OCC)[C@H](C)Cc1ccc(OC)c(S(N)(=O)=O)c1</smiles>

5- $[(2 \mathrm{R})-2-[\mathrm{bis}[2-(2-$ ethoxyphenoxy)ethyl]amino] propyl]-2-methoxy benzenesulfonamide

H. TAM-3 (EP-A)<smiles>COc1ccccc1OCCNCCCc1ccc(OC)c(S(N)(=O)=O)c1</smiles>

2-methoxy-5-(2R)- $\{[2-(2-$ methoxy phenoxy) ethyl] amino propyl\} benzene sulphonamide F. TAM-1 (EP-D)<smiles>[R]c1cc(C[C@@H](C)NCCOc2ccccc2[R2])ccc1OC</smiles>

$\mathrm{R} 1=\mathrm{SO} 2-\mathrm{NH} 2, \mathrm{R} 2=\mathrm{H}: 2-$ methoxy-5-[(2R)-2-[(2phenoxyethyl)amino]prop yl]benzenesulfonamide

I. TAM-4 (EP-C)

Figure 1. Chemical structure of solifenacin and tamsulosin, and their impurities (A. Tamsulosin (TAM); B. Solifenacin (SOL); C. SOL-1/ N-Oxide; D. SOL-2/S-IQL; E. SOL-3/S-IQL-CARB; F. TAM-1 (EP-D); G. TAM-2 (EP-H); H. TAM-3 (EP-A) and I. TAM-4 (EP-C)).

mal stability studies were performed in a dry air oven (Thermo scientific). Mobile phase was degassed by ultra-sonication (Power sonic 420, Labtech) and filtered through 
a $0.45 \mu \mathrm{m}$ Nylon filter (PALL life sciences, USA).

\subsection{Related Substances, Assay Standard and Sample Preparation}

\section{Preparation of Standard Solutions:}

A stock solution of SOL and TAM (5000 $\mu \mathrm{g} \cdot \mathrm{mL}^{-1}$ of SOL and $332 \mu \mathrm{g} \cdot \mathrm{mL}^{-1}$ of TAM) was prepared by dissolving appropriate amount of drugs in diluent (Milli-Q water and Acetonitrile 50:50 v/v). Working solutions of $24 \mu \mathrm{g} \cdot \mathrm{mL}^{-1}$ of SOL and $1.6 \mu \mathrm{g} \cdot \mathrm{mL}^{-1}$ of $\mathrm{TAM}$, and $150 \mu \mathrm{g} \cdot \mathrm{mL}^{-1}$ of SOL and $10 \mu \mathrm{g} \cdot \mathrm{mL}^{-1}$ of TAM were prepared from the above stock solution for related substance and assay determination respectively. Individual impurity stock solutions were prepared in diluent.

Preparation of Sample Solution:

Tablet powder (6/0.4 mg tablets) equivalent to $120 \mathrm{mg}$ of SOL (8 mg of TAM) drug was dissolved in diluent with sonication for $20 \mathrm{~min}$ to give a solution containing 4800 $\mu \mathrm{g} \cdot \mathrm{mL}^{-1}$ of SOL and $320 \mu \mathrm{g} \cdot \mathrm{mL}^{-1}$ of TAM. The above solution was centrifuged at 4000 rpm for 5 minutes in order to eliminate insoluble excipients. The supernatant liquid was used for RS analysis. A solution with $144 \mu \mathrm{g} \cdot \mathrm{mL}^{-1}$ of SOL and $10 \mu \mathrm{g} \cdot \mathrm{mL}^{-1}$ of TAM were prepared by diluting supernatant solution for Assay analysis.

\subsection{Chromatographic Conditions}

The method was developed using Capcell Pak C18, MG, $150 \times 4.6 \mathrm{~mm} ; 5 \mu \mathrm{m}$ column (Shiseido, Japan) with mobile phase containing a gradient mixture of solvent A and B. $20 \mathrm{mM}$ Monobasic potassium phosphate buffer with $0.5 \%$ triethylamine, $\mathrm{pH}$ adjusted to 6.6 with phosphoric acid was used as solvent-A and Milli-Q water and acetonitrile in the ratio $10: 90 \mathrm{v} / \mathrm{v}$; was used as solvent- $\mathrm{B}$. The gradient program $(\mathrm{T} / \% \mathrm{~B})$ was set as $0 / 20,10 / 40,15 / 40,22 / 70,37 / 70,38 / 20$ and $45 / 20$. The flow rate of the mobile phase was $0.9 \mathrm{~mL} \cdot \mathrm{min}^{-1}$. The column temperature was maintained at $30^{\circ} \mathrm{C}$ and the chromatography was monitored at $225 \mathrm{~nm}$. Injection volume was $10 \mu \mathrm{L}$.

\section{Method Validation}

The objective of validation of an analytical procedure is to demonstrate that it is suitable for its intended purpose. The method was validated according to International Council for Harmonisation Q2 (R1) guidelines [25] for validation of analytical procedures in order to determine the specificity, linearity, limit of detection, limit of quantification, accuracy, precision and robustness.

\subsection{Solution Stability}

The stability of SOL and TAM in solution for assay was determined by leaving test solutions of the sample and reference standards in tightly capped volumetric flasks at room temperature were assayed at $12 \mathrm{hrs}$ intervals up to $24 \mathrm{hrs}$. The stability of SOL and TAM and their impurities in solution for related substance method was determined by leaving spiked sample solution in a tightly capped volumetric flask at room temperature for $24 \mathrm{hrs}$ and measuring the amounts of the five impurities at every $12 \mathrm{hrs}$. 


\subsection{Specificity}

Specificity is the ability of the method to measure the analyte response in the presence of its potential impurities. The specificity of the developed LC method for SOL and TAM was carried out in presence of its seven impurities. Stress studies were performed at the concentration $4800 \mu \mathrm{g} \cdot \mathrm{mL}^{-1}$ of SOL and $320 \mu \mathrm{g} \cdot \mathrm{mL}^{-1}$ of TAM on API in presence of excipients to show the stability indicating property of the method. The forced degradation was carried out on individual APIs to prove that degradents are not co-eluting with any of the known impurities and active molecule.

Intentional degradation was attempted to stress condition of UV light (200 watt hr/ $\left.\mathrm{m}^{2}\right)$, Sun-light $\left(1.2 \mathrm{Mill}\right.$ lux hrs), heat $\left(60^{\circ} \mathrm{C}\right.$ for $\left.15 \mathrm{hr}\right)$, acid $\left(1 \mathrm{~N} \mathrm{HCl}\right.$ at $60^{\circ} \mathrm{C}$ for $\left.18 \mathrm{hr}\right)$, base $\left(1 \mathrm{~N} \mathrm{NaOH}\right.$ at $60^{\circ} \mathrm{C}$ for $18 \mathrm{hr}$ ), water $\left(\right.$ at $60^{\circ} \mathrm{C}$ for $24 \mathrm{hr}$ ) and oxidation $\left(1.0 \% \mathrm{H}_{2} \mathrm{O}_{2}\right.$ at RT for $15 \mathrm{hr}$ ) for SOL and TAM to evaluate the ability of the proposed method to separate SOL and TAM from their degradation products. Peak purity test was carried out for SOL and TAM peaks by using PDA detector for stress samples.

\subsection{Linearity}

Linearity test solutions for SOL and TAM and their impurities were prepared by diluting stock solutions to required concentrations. The solutions were prepared at six concentration levels from LOQ to $200 \%$ of the specification level $0.5 \%$ (LOQ, $0.10 \%, 0.25 \%$, $0.50 \%, 0.75 \%$ and $1.0 \%)$. Linearity test solutions for the assay method were prepared from SOL and TAM stock solutions at 6 concentration levels from $50 \%$ to $200 \%$ of assay concentration $(50 \%, 75 \%, 100 \%, 125 \%, 150 \%$ and $200 \%$ for SOL and TAM). The peak area versus concentration data was treated by least-squares linear regression analysis.

\subsection{Limits of Detection (LOD) and Quantification (LOQ)}

The LOD and LOQ for SOL and TAM and their impurities were determined at a signalto-noise ratio of 3:1 and 10:1, respectively, by injecting a series of dilute solutions with known concentrations. Precision study was also carried out at the LOQ level by injecting six individual preparations and calculated \% RSD.

\subsection{Accuracy}

The accuracy of the assay method was evaluated in triplicate at five concentration levels $50 \%, 75 \%, 100 \%, 150 \%$ and $200 \%$ on tablets $(6 / 0.4 \mathrm{mg})$. Standards of SOL, TAM and their impurities were spiked at different concentration levels namely LOQ, $0.25 \%, 0.5 \%$, $0.75 \%$ and $1.0 \%$ with respect to their test concentration in triplicate and evaluated for accuracy of impurities. The percentage of recoveries for SOL, TAM and their impurities were calculated.

\subsection{Precision}

The precision of the method was verified by injecting six individual preparations of dosage form (SOL $6 \mathrm{mg}$ and TAM $0.4 \mathrm{mg}$ ) spiked with $0.5 \%$ of its impurities. SOL im- 
purities are spiked at $0.5 \%$ with respect to SOL concentration $4800 \mu \mathrm{g} \cdot \mathrm{mL}^{-1}$ and TAM impurities are spiked at $0.5 \%$ with respect to TAM concentration $320 \mu \mathrm{g} \cdot \mathrm{mL}^{-1}$. \% RSD of each impurity was calculated. Assay method precision was evaluated by carrying out six independent test preparations of SOL \& TAM at $144 \mu \mathrm{g} \cdot \mathrm{mL}^{-1}$ of SOL and $10 \mu \mathrm{g} \cdot \mathrm{mL}^{-1}$ of TAM against qualified reference standard.

The same experiment was repeated on different day with different chromatographic system and different analyst to find variability.

\subsection{Robustness}

To determine the robustness of the method, experimental conditions were deliberately altered and the resolution between SOL and TAM impurities and tailing factors for SOL and TAM and their impurities were recorded. The effect of flow rate was evaluated at 0.7 and $1.1 \mathrm{~mL} \cdot \mathrm{min}^{-1}$ instead of $0.9 \mathrm{~mL} \cdot \mathrm{min}^{-1}$. The effect of the column temperature was studied at $25^{\circ} \mathrm{C}$ and $35^{\circ} \mathrm{C}$ instead of $30^{\circ} \mathrm{C}$. The effect of $\mathrm{pH}$ of mobile phase buffer was studied by varying $\mathrm{pH} \pm 0.1$ units of method $\mathrm{pH}$ (6.6) keeping other mobile phase components constant.

\section{Results}

\subsection{Method Development}

The main target of the chromatographic method is to get the separation of impurities namely SOL-1, SOL-2 and SOL-3 of SOL \& TAM-1, TAM-2, TAM-3 and TAM-4 of TAM and the degradation products generated during stress studies from the analyte peaks along with the actives.

Chromatographic conditions with Capcell Pak C18, MG, $150 \times 4.6 \mathrm{~mm} ; 5 \mu \mathrm{m}$ column and the mobile phase consists of solvent-A (20 mM Monobasic potassium phosphate buffer with $0.5 \%$ triethylamine, $\mathrm{pH}$ adjusted to 6.6 with phosphoric acid) and solvent-B (Milli-Q water and acetonitrile in the ratio of 10:90 v/v), with gradient program $(\mathrm{T} / \% \mathrm{~B})$ was set as $0 / 20,10 / 40,15 / 40,22 / 70,37 / 70,38 / 20$ and $45 / 20$. The flow rate of the mobile phase was $0.9 \mathrm{~mL} \cdot \mathrm{min}^{-1}$. The column temperature was maintained at $30^{\circ} \mathrm{C}$ and the chromatography was monitored at $225 \mathrm{~nm}$. Injection volume as $10 \mu \mathrm{L}$ was suitable in separating SOL, TAM and its impurities from one other (Figure 2(A) \& Figure 2(B)). Details of relative retention time, relative response factor, resolution and tailing factor values are summarized in Table 1 .

\subsection{Method Validation}

Validation was performed on the developed analytical method for its acceptable performance to ensure suitability of intend purpose. The validation parameters like accuracy, precision, specificity, detection limit, quantification limit, linearity, range, ruggedness and robustness were executed and established method conditions to meet the requirements to execute the analysis of SOL and TAM combination dosage product. Under the specificity experiment samples were stressed at various stress conditions and analyzed along with unstressed samples. During the stress studies it was observed SOL 

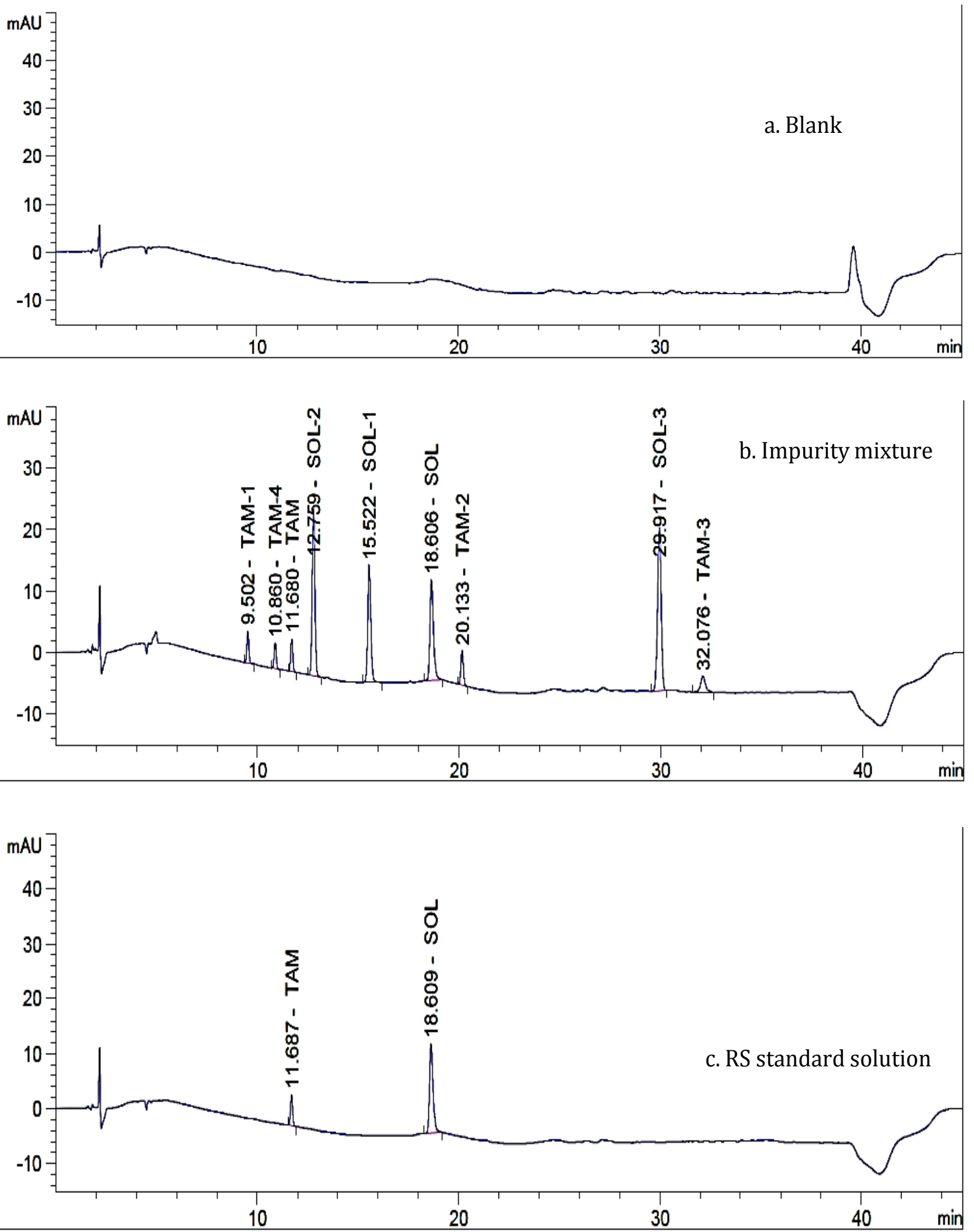

(A) 

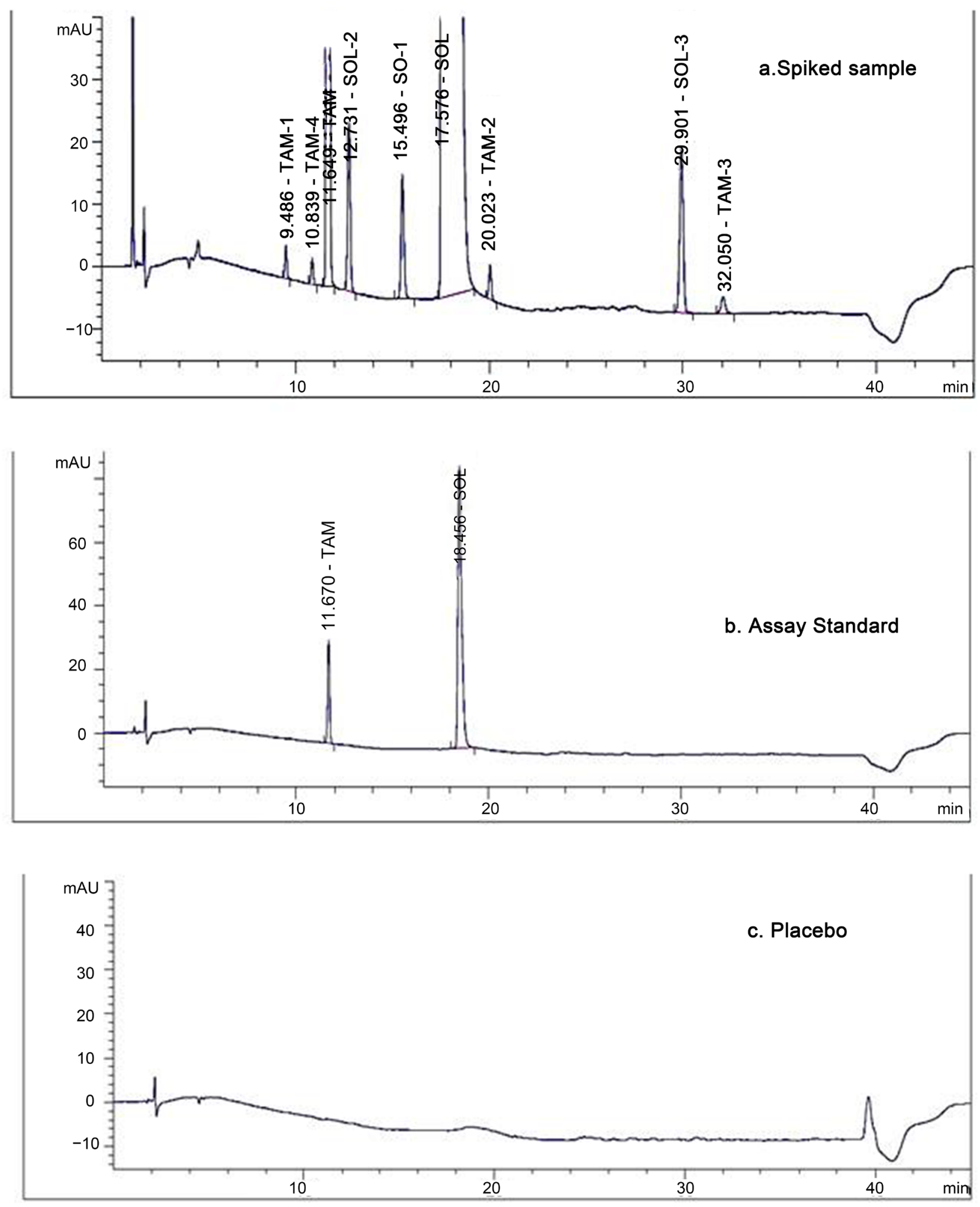

(B)

Figure 2. (A) Typical chromatograms of solifenacin and tamsulosin at $225 \mathrm{~nm}$ (a. blank, b. impurity mixture and c. RS standard solution); (B) Typical chromatograms of solifenacin and tamsulosin at $225 \mathrm{~nm}$ (a. spiked sample, b. assay standard and c. placebo). 
Table 1. Factor values of chromatographic method.

\begin{tabular}{cccccc}
\hline Compound & RT(min) & RRT $^{*}$ & RRF & Resolution & Tailing factor \\
\hline TAM-1 & 9.486 & 0.81 & 0.94 & N/A & 1.00 \\
TAM-4 & 10.839 & 0.93 & 0.82 & 6.90 & 1.01 \\
TAM & 11.649 & 1.0 & 1.0 & 4.02 & 0.99 \\
SOL-2 & 12.731 & 0.72 & 1.30 & 4.96 & 1.03 \\
SOL-1 & 15.496 & 0.88 & 1.03 & 10.65 & 1.08 \\
SOL & 17.576 & 1.0 & 1.0 & 3.68 & 1.15 \\
TAM-2 & 20.023 & 1.72 & 1.19 & 4.70 & 1.00 \\
SOL-3 & 29.901 & 1.70 & 1.73 & 34.32 & 0.98 \\
TAM-3 & 32.050 & 2.75 & 1.12 & 6.12 & 1.13 \\
\hline
\end{tabular}

${ }^{*}$ Relative retention times (RRT) for TAM-1, TAM-2, TAM-3 and TAM- 4 were calculated against the retention time (RT) of Tamsulosin and RRT of SOL-1, SOL-2 and SOL-3 were calculated against the retention time (RT) of Solifenacin.

and TAM were degraded significantly at particular conditions. SOL-1 impurity observed at oxidative $\left(1 \% \mathrm{H}_{2} \mathrm{O}_{2}\right.$ at $25^{\circ} \mathrm{C}$ for $15 \mathrm{~h}$ ) condition (Figure $3(\mathrm{C})$ ) and SOL-2 \& TAM-4 impurities observed at base hydrolysis $\left(1 \mathrm{~N} \mathrm{NaOH}\right.$ at $60^{\circ} \mathrm{C}$ for $\left.18 \mathrm{~h}\right)$ condition (Figure 3(B) \& Figure 4(B)). TAM-2 and one major unknown impurity at $25.985 \mathrm{~min}$ were observed at oxidative $\left(1 \% \mathrm{H}_{2} \mathrm{O}_{2}\right.$ at $25^{\circ} \mathrm{C}$ for $15 \mathrm{~h}$ ) condition (Figure $4(\mathrm{C})$ ). Results of forced degradation studies are reported in Table 2. Linearity, limit of quantification, limit of detection, precision, intermediate precision and precision at LOQ for SOL, TAM and its impurities were established and presented in Table 3. The percentage recovery of SOL, TAM and impurities in the estimation of impurities are presented in Table 4. Linearity, precision and intermediate precision results of SOL \& TAM in the assay determination are presented in Table 5 . The percentage recovery results for SOL $\&$ TAM in the assay determination are presented in Table 6.

\section{Discussion}

\subsection{Method Development}

The main target of the chromatographic method is to achieve the separation of impurities and the main components SOL \& TAM with each other. A blended solution containing SOL impurities are spiked at $0.5 \%$ with respect to SOL concentration at 4800 $\mu \mathrm{g} \cdot \mathrm{mL}^{-1}$ and TAM impurities are spiked at $0.5 \%$ with respect to TAM concentration at $320 \mu \mathrm{g} \cdot \mathrm{mL}^{-1}$ was prepared in diluent and used for the method's development. Initial experiments were performed with $20 \mathrm{mM}$ monobasic potassium phosphate buffer $(\mathrm{pH}$ 6.5) as solvent-A and $90 \%$ acetonitrile as solvent- $\mathrm{B}$ with different gradient programs, using Inertsil ODS-3V (C-18, 150-mm 4.6- $\mathrm{mm}, 5 \mu \mathrm{m}$ particles) column and found TAM-1, TAM-4, TAM peaks merged together and SOL-2, TAM-2 TAM-3 impurities response and peak shape found not good. Further checked with different stationery phase column Kromasil (C8, 150-mm 4.0-mm, $5 \mu \mathrm{m}$ particles) and found TAM-1, 

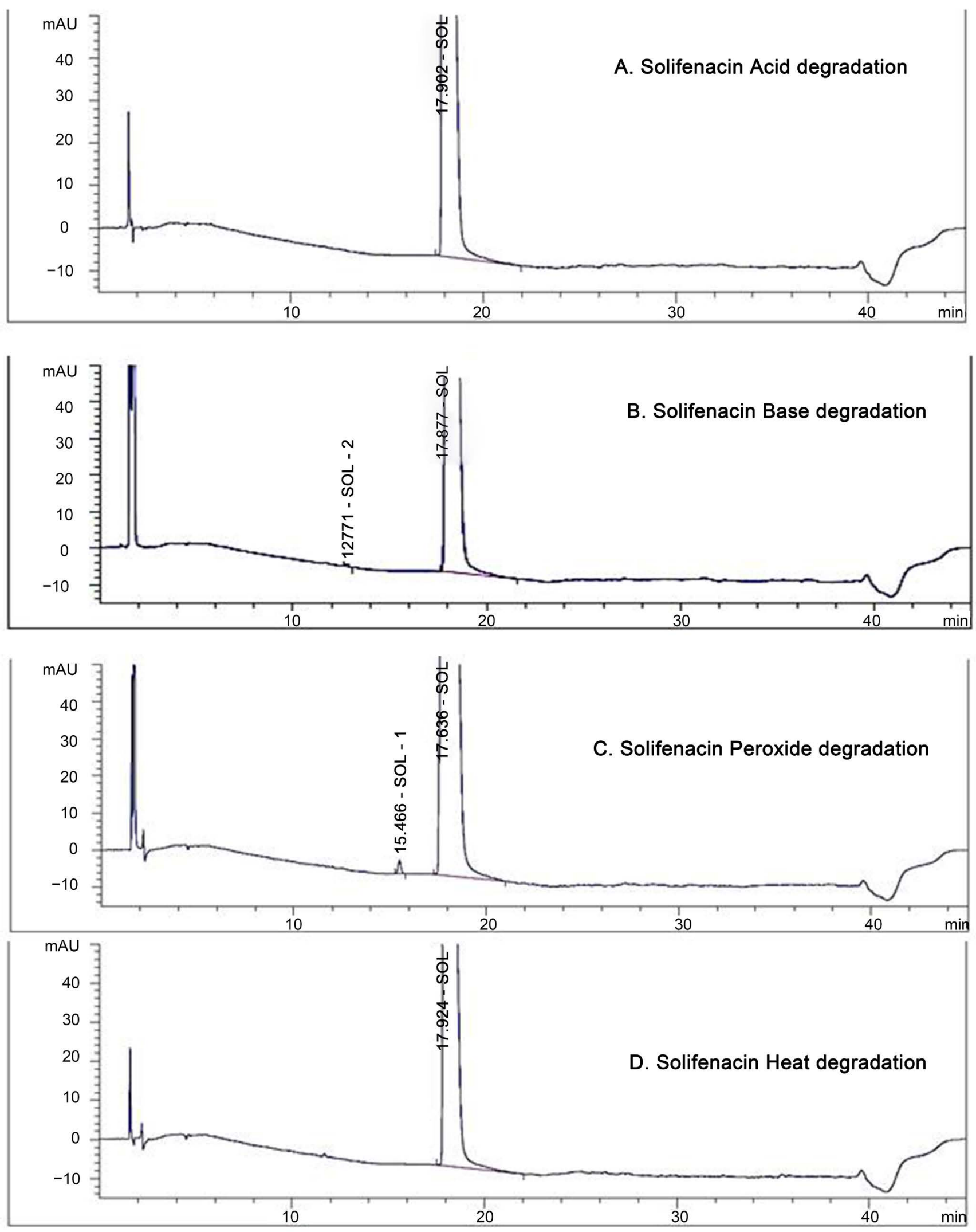

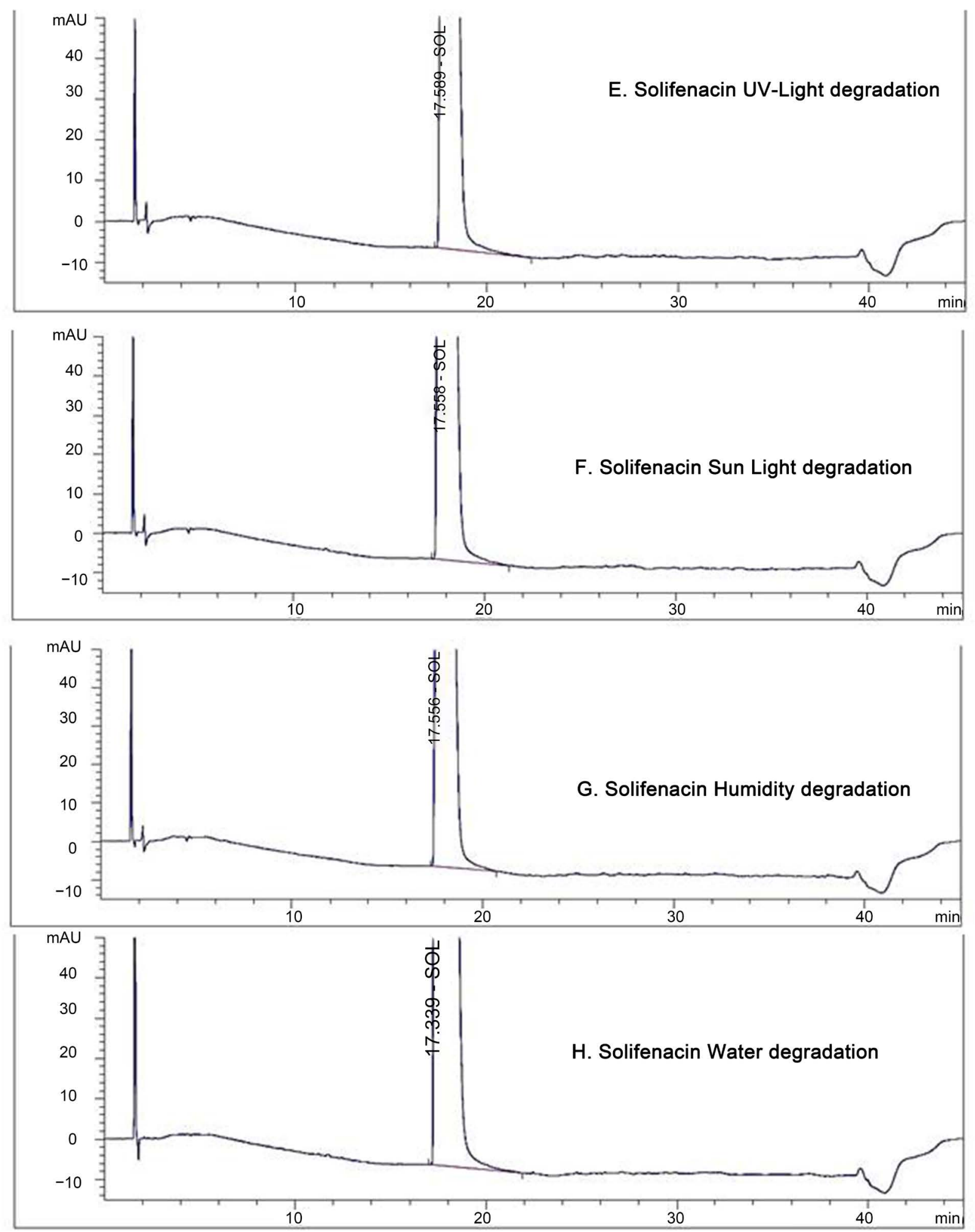

Figure 3. Typical chromatograms of solifenacin at $225 \mathrm{~nm}$ (forced degradation study) (A. Solifenacin acid degradation; B. Solifenacin base degradation; C. Solifenacin peroxide degradation and D. Solifenacin heat degradation); Typical chromatograms of solifenacin at $225 \mathrm{~nm}$ (forced degradation study) (E. Solifenacin UV-light degradation; F. Solifenacin sunlight degradation; G. Sol ifenacin humidity degradation and H. Solifenacin water degradation). 

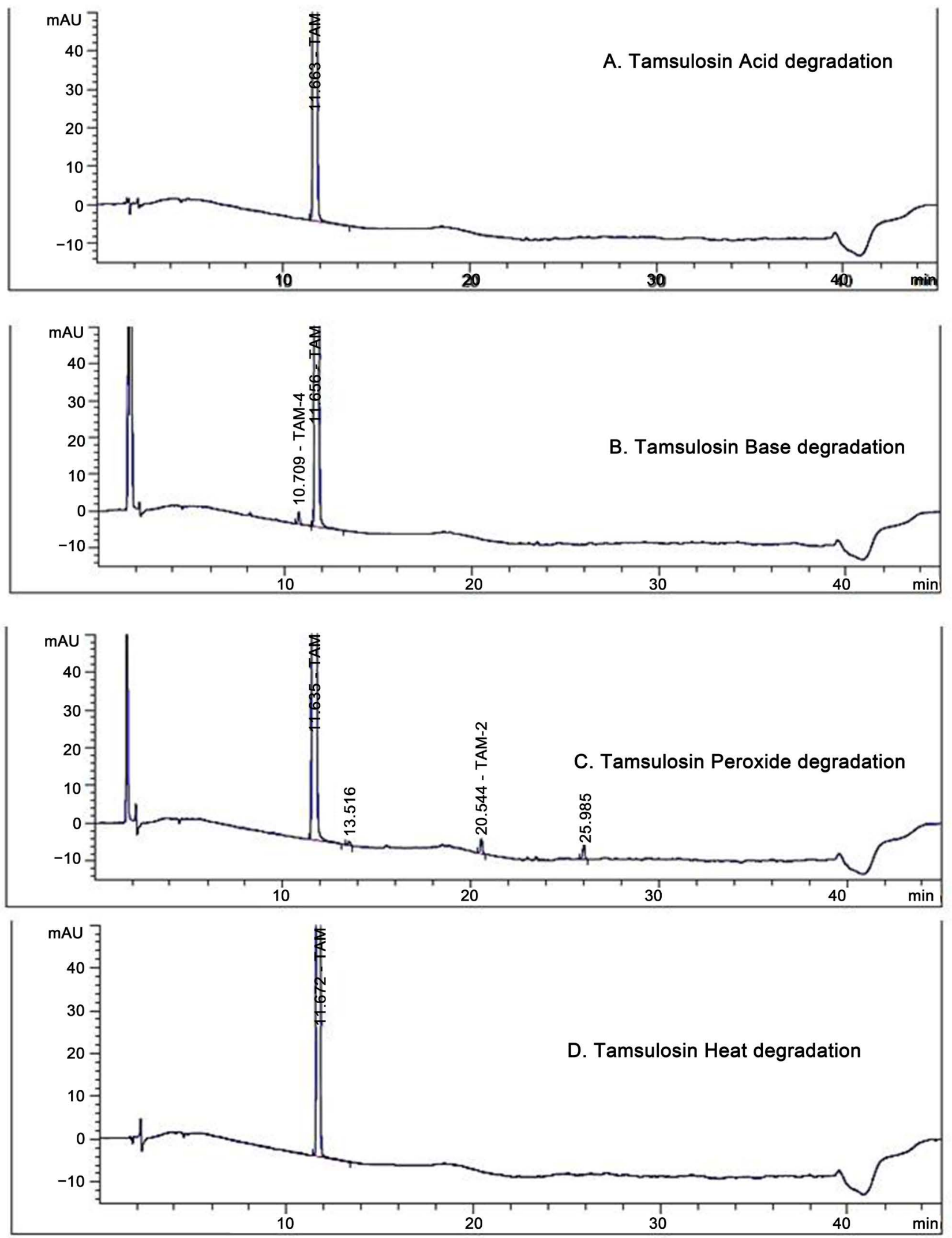

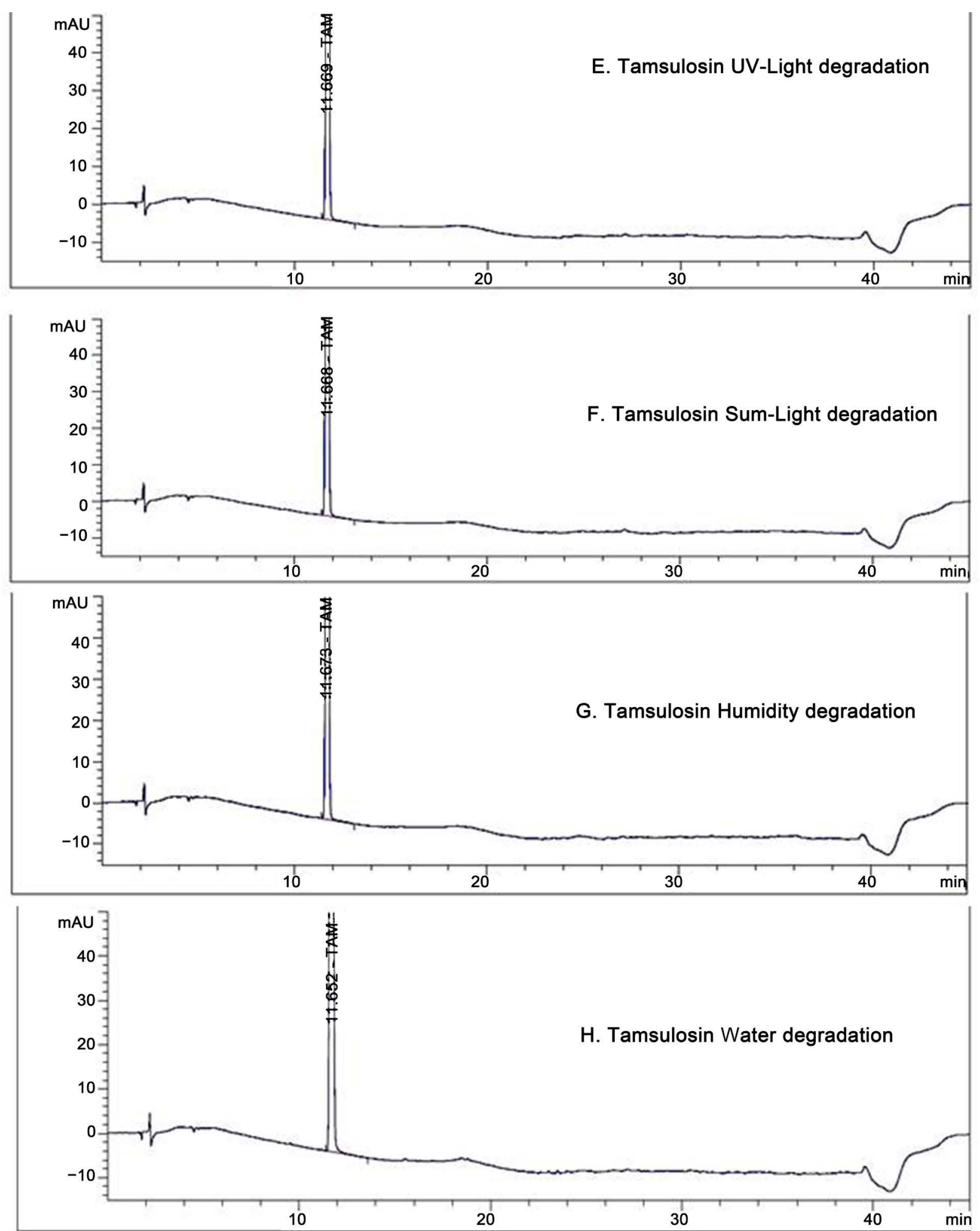

Figure 4. Typical chromatograms of tamsulosin at $225 \mathrm{~nm}$ (forced degradation study) (A. Tamsulosin acid degradation; B. Tamsulosin base degradation; C. Tamsulosin peroxide degradation and D. Tamsulosin heat degradation); Typical chromatograms of solifenacin at $225 \mathrm{~nm}$ (forced degradation study) (E. Tamsulosin UV-light degradation; F. Tamsulosin sun-light degradation; G. Tamsulosin humidity degradation and H. Tamsulosin water degradation). 
Table 2. Specificity.

\begin{tabular}{|c|c|c|c|c|c|c|c|c|}
\hline \multirow{3}{*}{$\begin{array}{c}\text { Stress condition } \\
\text { (Degradation) }\end{array}$} & \multicolumn{6}{|c|}{$\%$ of impurities formed ( $\%$ of area normalization) } & \multirow{2}{*}{\multicolumn{2}{|c|}{ Peak purity $\dagger$}} \\
\hline & \multirow{2}{*}{ 㫄 } & \multirow{2}{*}{ 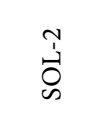 } & \multirow{2}{*}{$\sum_{5}^{+1}$} & \multirow{2}{*}{$\sum_{\stackrel{S}{H}}^{N}$} & \multirow{2}{*}{$\begin{array}{l}\text { Unknown } \\
25.985 \mathrm{RT}\end{array}$} & \multirow[b]{2}{*}{$\%$ of degradation } & & \\
\hline & & & & & & & TAM & SOL \\
\hline As such sample & $\mathrm{ND}^{*}$ & ND & ND & ND & ND & ND & 997.501 & 997.750 \\
\hline Oxidation & 0.1196 & ND & ND & 0.1583 & 0.1673 & 0.491 & 999.485 & 999.879 \\
\hline Thermal & ND & ND & ND & ND & ND & ND & 999.777 & 999.869 \\
\hline Water & ND & ND & ND & ND & ND & ND & 997.713 & 999.836 \\
\hline UV & ND & ND & ND & ND & ND & ND & 999.534 & 999.899 \\
\hline SUN & ND & ND & ND & ND & ND & ND & 999.418 & 999.907 \\
\hline
\end{tabular}

${ }^{*}$ ND-Not detected; $\uparrow$ Peak purity numbers represented as per Agilent Chemstation software algorithm. Peak is pure only if purity value is more than 990.

Table 3. Regression and precision data.

\begin{tabular}{cccccccccc}
\hline PARAMETER & TAM & SOL & TAM-1 & TAM-2 & TAM-3 & TAM-4 & SOL-1 & SOL-2 & SOL-3 \\
\hline LOD $(\mu \mathrm{g} / \mathrm{mL})$ & 0.0135 & 0.0750 & 0.0153 & 0.0154 & 0.0306 & 0.0198 & 0.0538 & 0.0437 & 0.0451 \\
LOQ $(\mu \mathrm{g} / \mathrm{mL})$ & 0.0432 & 0.2211 & 0.0466 & 0.0432 & 0.0897 & 0.0610 & 0.1630 & 0.1346 & 0.1362 \\
Correlation coefficient & 0.9998 & 0.9998 & 1.0000 & 1.0000 & 0.9998 & 1.0000 & 0.9997 & 1.0000 & 1.0000 \\
Bias at 100\% response & 0.7791 & 0.5462 & 0.4888 & 0.4198 & 1.0061 & 0.1943 & 1.1538 & 0.3881 & 0.4176 \\
Precision (\%RSD) & 1.3 & 2.0 & 2.3 & 3.4 & 1.5 & 2.1 & 2.6 & 0.6 & 1.1 \\
Intermediate precision (\%RSD) & 0.7 & 1.0 & 1.6 & 1.2 & 1.2 & 0.8 & 0.4 & 2.0 & 1.6 \\
Precision at LOQ (\%RSD) & 2.9 & 3.5 & 4.2 & 4.5 & 2.0 & 2.8 & 3.4 & 2.7 & 3.3 \\
\hline
\end{tabular}

Table 4. Evaluation of accuracy.

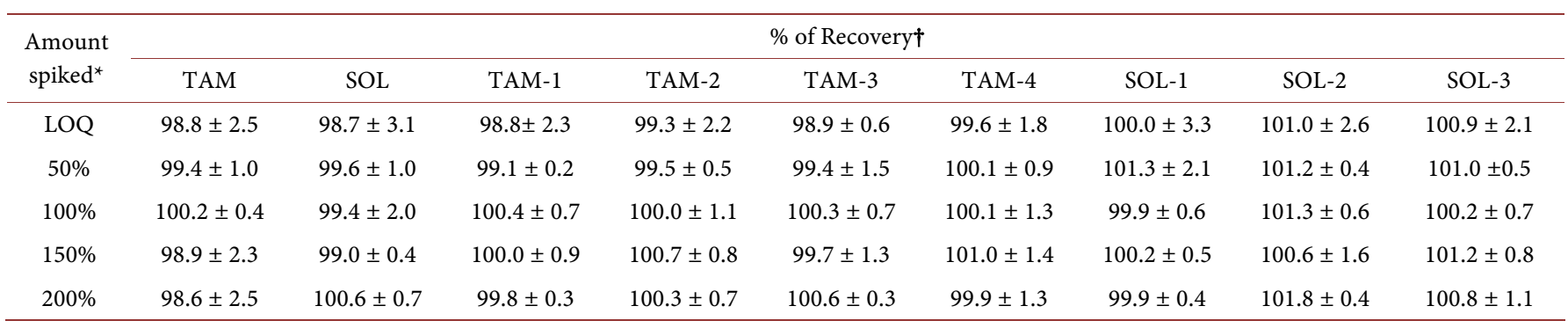

${ }^{*}$ Amount of seven impurities spiked with respect to $0.5 \%$ specification level individually to Tamsulosin and Solifenacin. $†$ Mean $\pm \%$ RSD for three determinations at each level.

Table 5. Regression and precision data-assay.

\begin{tabular}{ccc}
\hline PARAMETER & TAM & SOL \\
\hline Correlation coefficient & 0.9999 & 0.0000 \\
Bias at 100\% response & 1.2114 & 0.5568 \\
Precision (\%RSD) & 0.3 & 0.3 \\
Intermediate precision (\%RSD) & 0.2 & 0.1 \\
\hline
\end{tabular}


Table 6. Evaluation of accuracy in assay.

\begin{tabular}{ccc}
\hline \multirow{2}{*}{ Amount spiked $^{*}$} & \multicolumn{3}{c}{ \% of Recovery $\dagger$} \\
\cline { 2 - 3 } & TAM & SOL \\
\hline $50 \%$ & $99.8 \pm 0.9$ & $100.1 \pm 0.1$ \\
$75 \%$ & $100.2 \pm 0.5$ & $99.9 \pm 0.3$ \\
$100 \%$ & $99.9 \pm 0.2$ & $99.9 \pm 0.2$ \\
$150 \%$ & $100.0 \pm 0.2$ & $99.9 \pm 0.2$ \\
$200 \%$ & $100.1 \pm 0.3$ & $99.8 \pm 0.2$ \\
\hline
\end{tabular}

$\nmid$ Mean \pm RSD for three determinations at each level.

TAM-4 peak shapes not good. And SOL-2 peak not resolved well from TAM peak and TAM-2 peak co-eluted with SOL peak. Further checked with different brand C-18 column Hypersil BDS (C-18, 150-mm 4.6- $\mathrm{mm}, 5 \mu \mathrm{m}$ particles) and found resolution less than 2.0 between TAM \& SOL-2 peaks and TAM-2 peak co-eluted with SOL due to broad peak shape of SOL, which may be because of SOL interaction with residual silanol groups of stationary phase. Hence experiments were tried using Triethyl amine as mobile phase additive to end cap the silanol groups.

Triethylamine (TEA) is widely used as a mobile phase additive to reduce peak tailing when analyzing bases at neutral $\mathrm{pH}$. TEA acts as competing base, reducing the availability of stationary phase silanols and interaction of the analyte with the silanols.

To increase the resolution between SOL-2 \& TAM peaks and to resolve TAM-2 peak from SOL peak by reducing SOL peak broadness, introduced $0.5 \%$ Triethyl amine as organic modifier in solvent-A ( $20 \mathrm{mM}$ monobasic potassium phosphate buffer) at two different $\mathrm{pH}$ (6.5 \& 3.0) conditions respectively, and column used Hypersil BDS (C-18, $150-\mathrm{mm} 4.6-\mathrm{mm}, 5 \mu \mathrm{m}$ particles). $\mathrm{pH} 6.5$ buffer results found that resolution increased a little bit between SOL-2 \& TAM peaks and SOL peak broadness drastically decreased and TAM-2 peak resolved from SOL peak. $\mathrm{pH} 3.0$ buffer results found that TAM-1 \& TAM-4 peak shapes found not symmetric and resolution between SOL-1 \& SOL and SOL \& TAM-2 found less than 2.0. Among these experiments, buffer solution of mobile phase with $0.5 \%$ triethylamine $\mathrm{pH}$ adjusted to 6.5 with ortho phosphoric acid had shown better resolution and improved peak shapes, using C18 column. However it is necessary to improve the resolution between TAM \& SOL-2; SOL-1 \& SOL. Effect of variations was studied with respect to buffer $\mathrm{pH}$, flow rate and column oven temperature. Based on the experiments with different gradient programs a gradient program (T/\%B): $0 / 20,10 / 40,15 / 40,22 / 70,37 / 70,38 / 20$ and $45 / 20$ at detection wavelength 225 $\mathrm{nm}$ with the mobile phase consists of solvent-A (20 mM Monobasic potassium phosphate buffer with $0.5 \%$ triethylamine, $\mathrm{pH}$ adjusted to 6.6 with phosphoric acid) and solvent-B (Milli-q water and acetonitrile in the ratio 10:90 v/v), using Capcell Pak C18, MG, $150 \times 4.6 \mathrm{~mm} ; 5 \mu \mathrm{m}$ column was found suitable for separation of TAM, SOL and its impurities from each other at column oven temperature of $30^{\circ} \mathrm{C}$. The resolution between any two consecutive peaks is more than 2.0 and shapes of all peaks were found symmetric.

Trial chromatograms are shown in Figure 5(A) and Figure 5(B). 
a. Inertsil ODS-3V; $150 * 4.6 \mathrm{~mm} ; 5 \mu \mathrm{m} ; \mathrm{pH} 6.5$

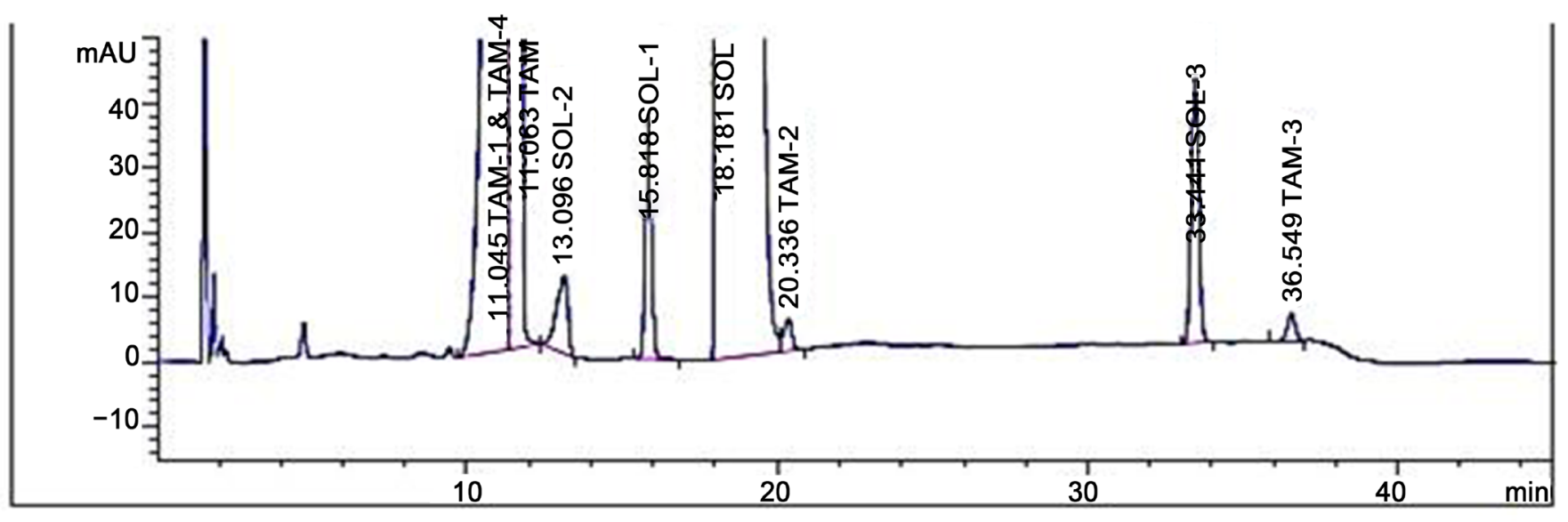

b. Kromasil C8; $150 * 4.0 \mathrm{~mm} ; 5 \mu \mathrm{m} ; \mathrm{pH} 6.5$

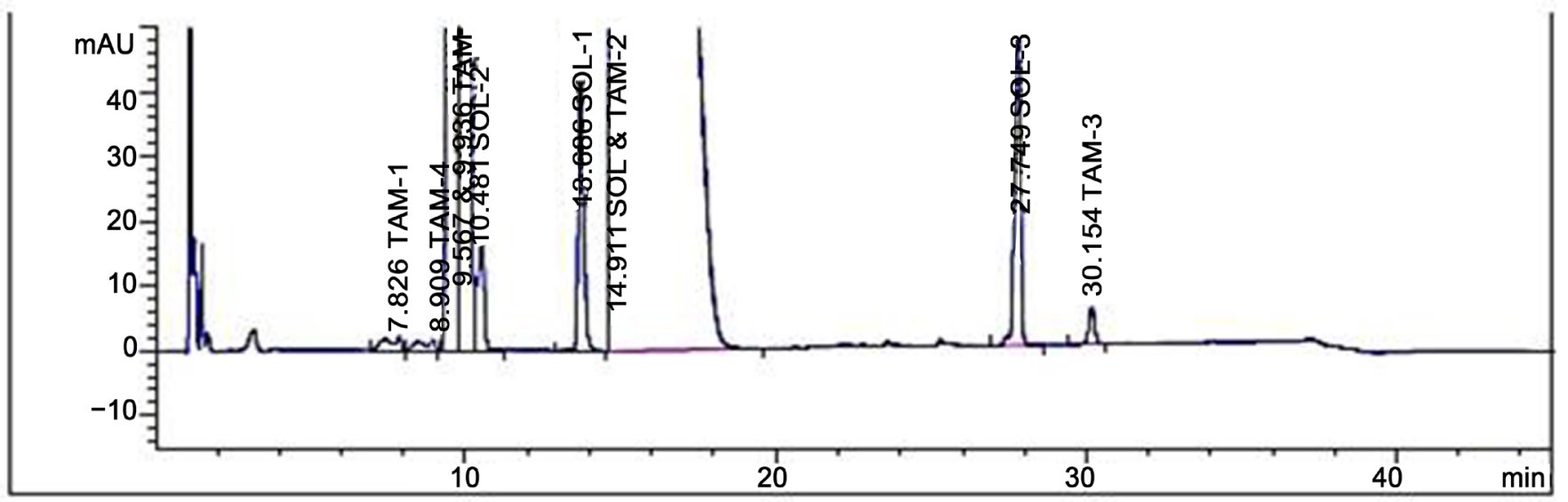

c. Hypersil BDS-C18; $150 * 4.6 \mathrm{~mm} ; 5 \mu \mathrm{m} ; \mathrm{pH} 6.5$

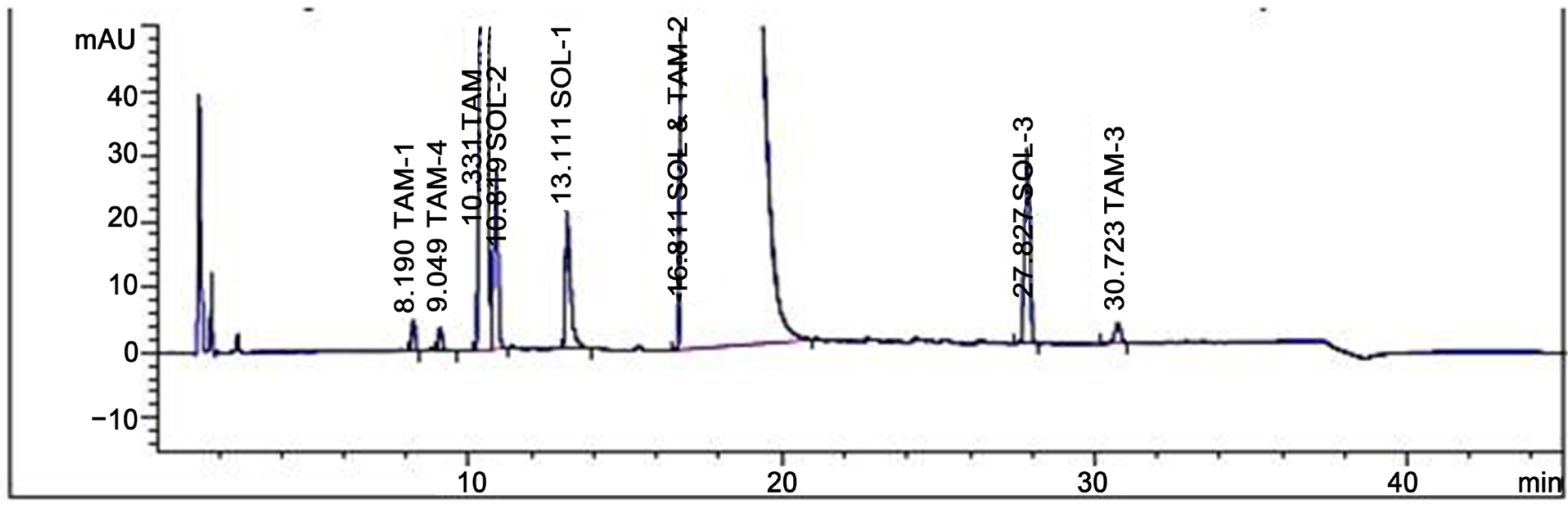

(A) 


\section{a. Hypersil BDS-C $18 ; 150 * 4.6 \mathrm{~mm} ; 5 \mu \mathrm{m} ; \mathrm{pH} 6.5+0.5 \%$ TEA}

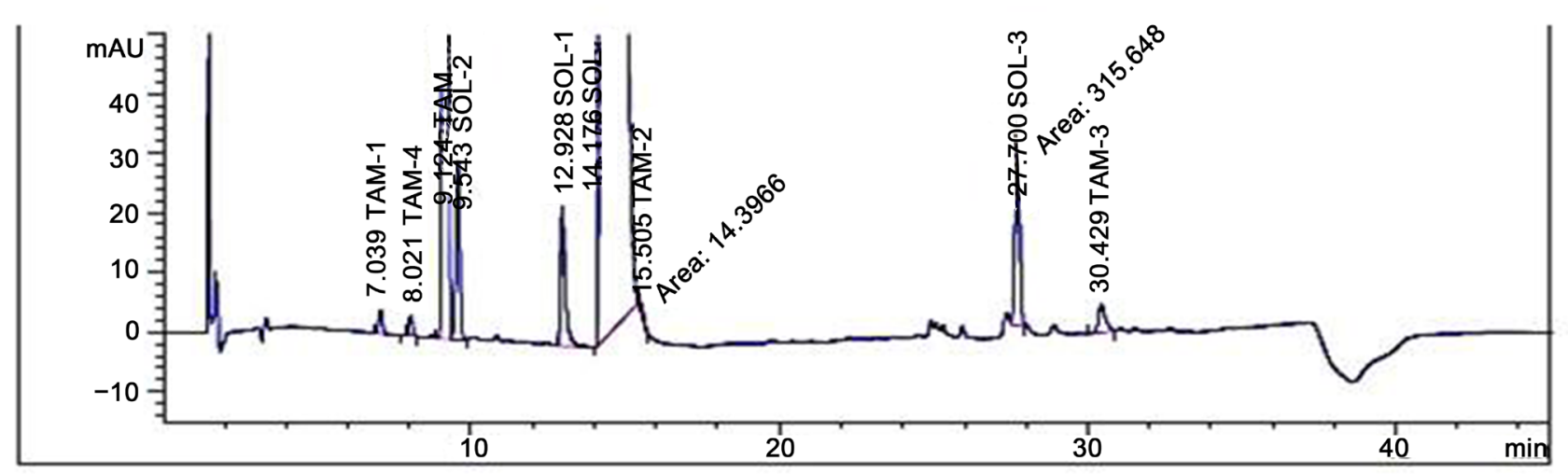

b. Hypersil BDS-C18; $150 * 4.6 \mathrm{~mm} ; 5 \mu \mathrm{m} ; \mathrm{pH} 3.0+0.5 \%$ TEA

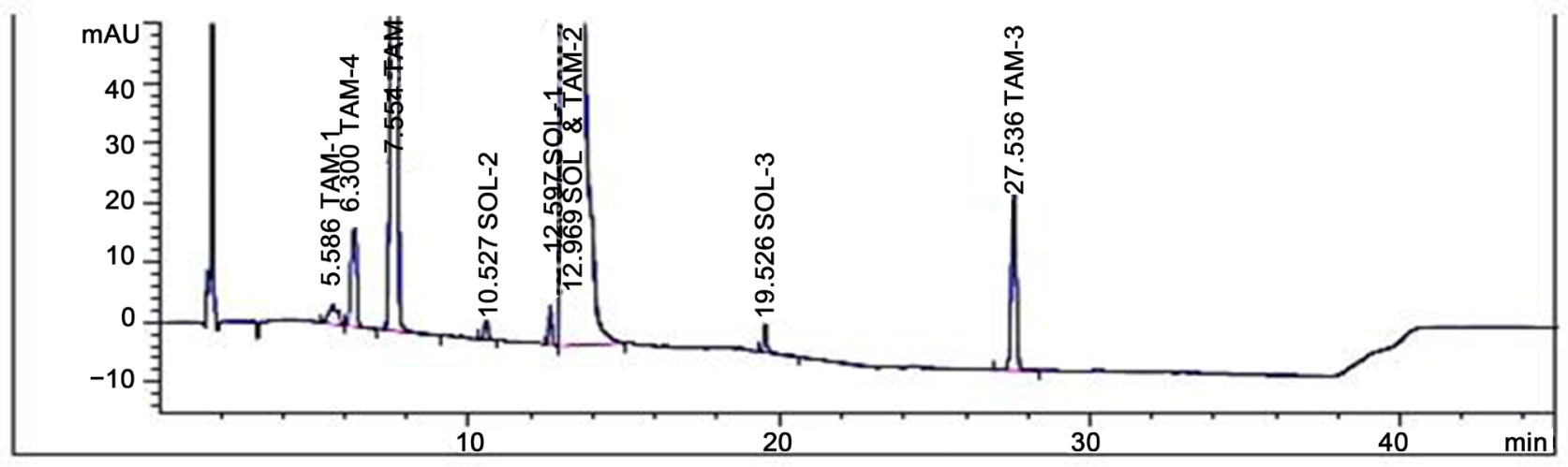

C. Capcell PAK C18-MG; $150 * 4.6 \mathrm{~mm} ; 5 \mu \mathrm{m} ; \mathrm{pH} 6.5+0.5 \%$ TEA

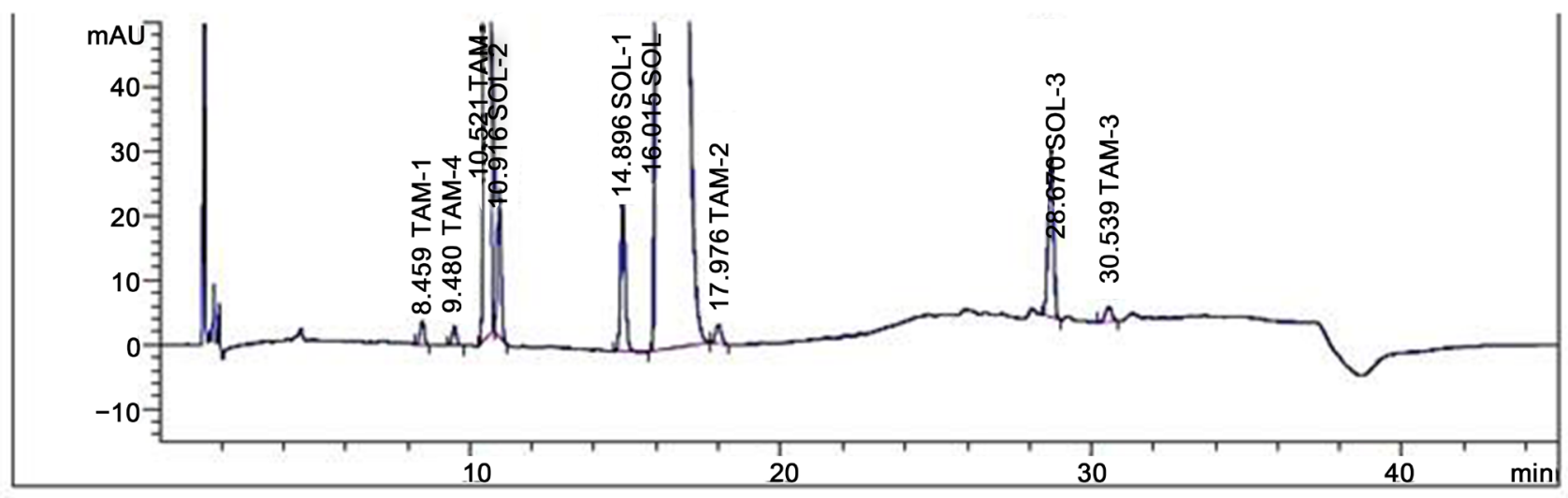

(B)

Figure 5. (A) Method development trial chromatograms column study Solvent-A pH at 6.5 (a. Inertsil ODS-3V; $150 \star 4.6 \mathrm{~mm} ; 5 \mu \mathrm{m} ; \mathrm{b}$. Kromasil C8; $150^{\star} 4.0 \mathrm{~mm} ; 5 \mu \mathrm{m}$ and c. Hypersil BDS-C18; $150^{\star} 4.6 \mathrm{~mm} ; 5 \mu \mathrm{m}$ ); (B) Method development trial chromatograms Solvent-A pH study at $6.5 \& 3.0$ with $0.5 \%$ TEA (a. Hypersil BDS-C18; $150 * 4.6 \mathrm{~mm} ; 5 \mu \mathrm{m} ; \mathrm{pH} 6.5+0.5 \%$ TEA; b. Hypersil BDS-C18; $150^{\star} 4.6 \mathrm{~mm} ; 5$ $\mu \mathrm{m} ; \mathrm{pH} 3.0+0.5 \%$ TEA and c. Capcell PAK C18-MG; $150 \star 4.6 \mathrm{~mm} ; 5 \mu \mathrm{m} ; \mathrm{pH} 6.5+0.5 \%$ TEA). 


\subsection{Wavelength Justification}

Wavelength was selected based on wavelength maxima of SOL, TAM and their known impurities UV spectrums. SOL and TAM have wavelength maxima at about $225 \mathrm{~nm}$ and their known impurities have sufficient absorbance for the measurement. Hence the 225 $\mathrm{nm}$ was selected as suitable wavelength for the estimation of impurities. The UV spectrums of SOL, TAM and their impurities has presented in Figure 6(A) \& Figure 6(B).

\subsection{Method Validation}

\subsubsection{Solution Stability}

Assay (\%) of both drugs during solution stability experiments were within $\pm 1 \%$. The variability in the estimation of SOL and TAM impurities were within $\pm 10 \%$ during solution stability experiment. The results from solution stability experiments confirmed that standard and sample solutions were stable up to $24 \mathrm{hrs}$ for both assay and related substances analysis.

\subsubsection{Specificity}

To confirm the specificity all the seven impurities were spiked on test solution and injected into the HPLC system with PDA detector. And the results found that no interference observed at SOL \& TAM peaks, hence this method is specific to its intended use.

All forced degradation samples were analyzed at an initial concentration 4800 $\mu \mathrm{g} \cdot \mathrm{mL}^{-1}$ of SOL and $320 \mu \mathrm{g} \cdot \mathrm{mL}^{-1}$ of TAM with LC conditions using PDA detector to ensure the homogeneity and purity of SOL and TAM peaks. During the stress studies it was observed SOL and TAM were degraded significantly at particular conditions. SOL-1 impurity observed at oxidative $\left(1 \% \mathrm{H}_{2} \mathrm{O}_{2}\right.$ at $25^{\circ} \mathrm{C}$ for $15 \mathrm{hr}$ ) condition (Figure $3(\mathrm{C})$ ) and SOL-2 \& TAM-4 impurities observed at base hydrolysis $\left(1 \mathrm{~N} \mathrm{NaOH}\right.$ at $60^{\circ} \mathrm{C}$ for $18 \mathrm{~h}$ ) condition (Figure 3(B) \& Figure 4(B)). TAM-2 and one major unknown impurity at 25.985 min were observed at oxidative $\left(1 \% \mathrm{H}_{2} \mathrm{O}_{2}\right.$ at $25^{\circ} \mathrm{C}$ for $\left.15 \mathrm{~h}\right)$ condition (Figure $4(\mathrm{C})$ ).

The peak purity test result derived from photo diode array detector (PDA) confirmed that SOL and TAM peaks were pure and homogeneous in all the analyzed stress conditions and thus confirms the stability-indicating power of the developed method. Results of forced degradation studies were reported in Table 2.

\subsubsection{Linearity}

The linearity calibration plot for the assay method was obtained over the calibration ranges tested and correlation coefficient obtained was greater than 0.999 (Table 5) for both SOL and TAM. Linear calibration plot for impurities was obtained over the calibration ranges tested, i.e. LOQ to $1.0 \%$ for impurities. The correlation coefficient obtained was greater than 0.998 (Table 3 ). The above result show that an excellent correlation existed between the peak area and the concentration of all seven impurities.

\subsubsection{Limits of Detection and Quantification}

The limit of detection and limit of quantification values were established based on the signal to noise ratios. Precision at LOQ values for SOL and TAM and its seven impure- 

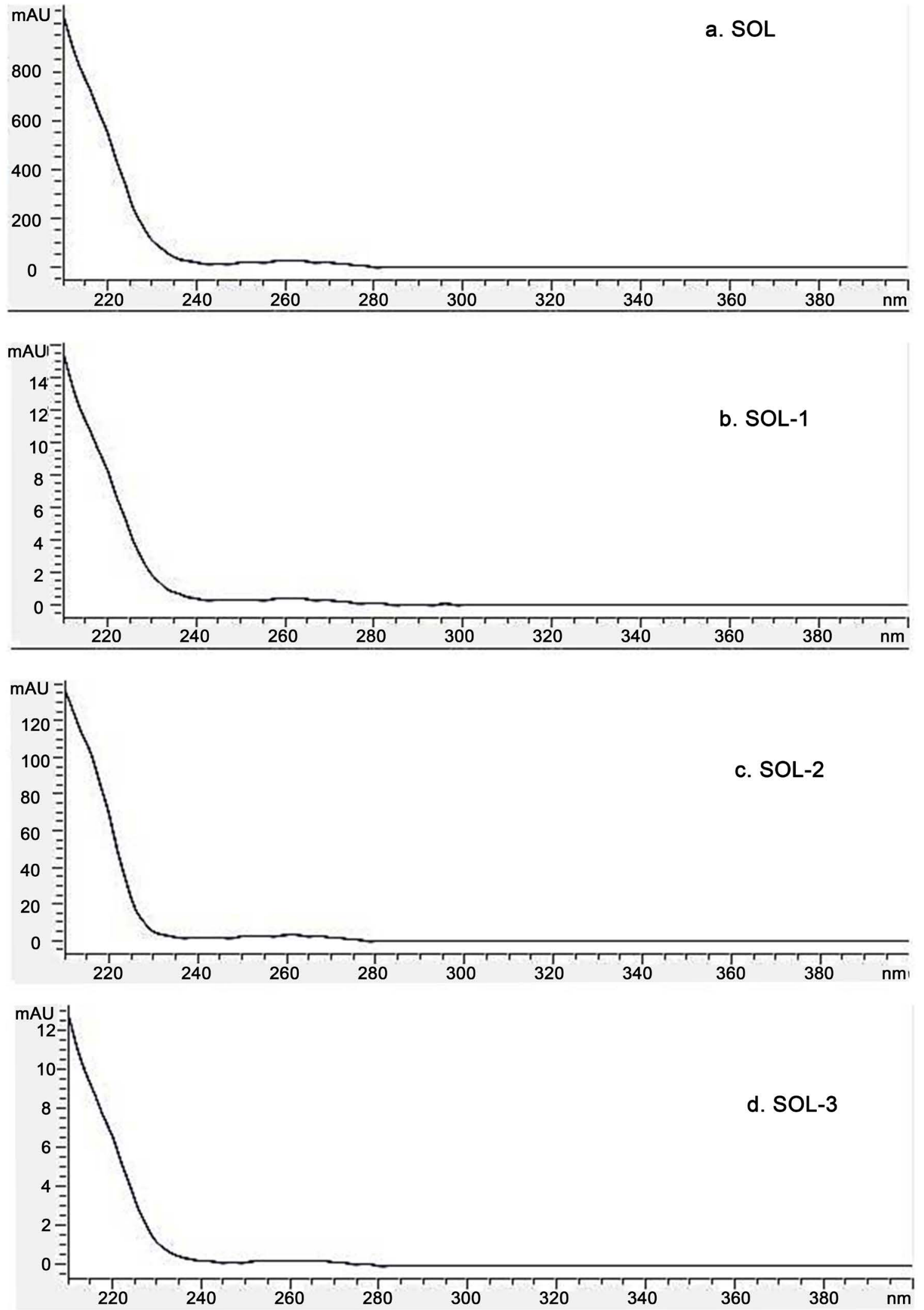

(A) 

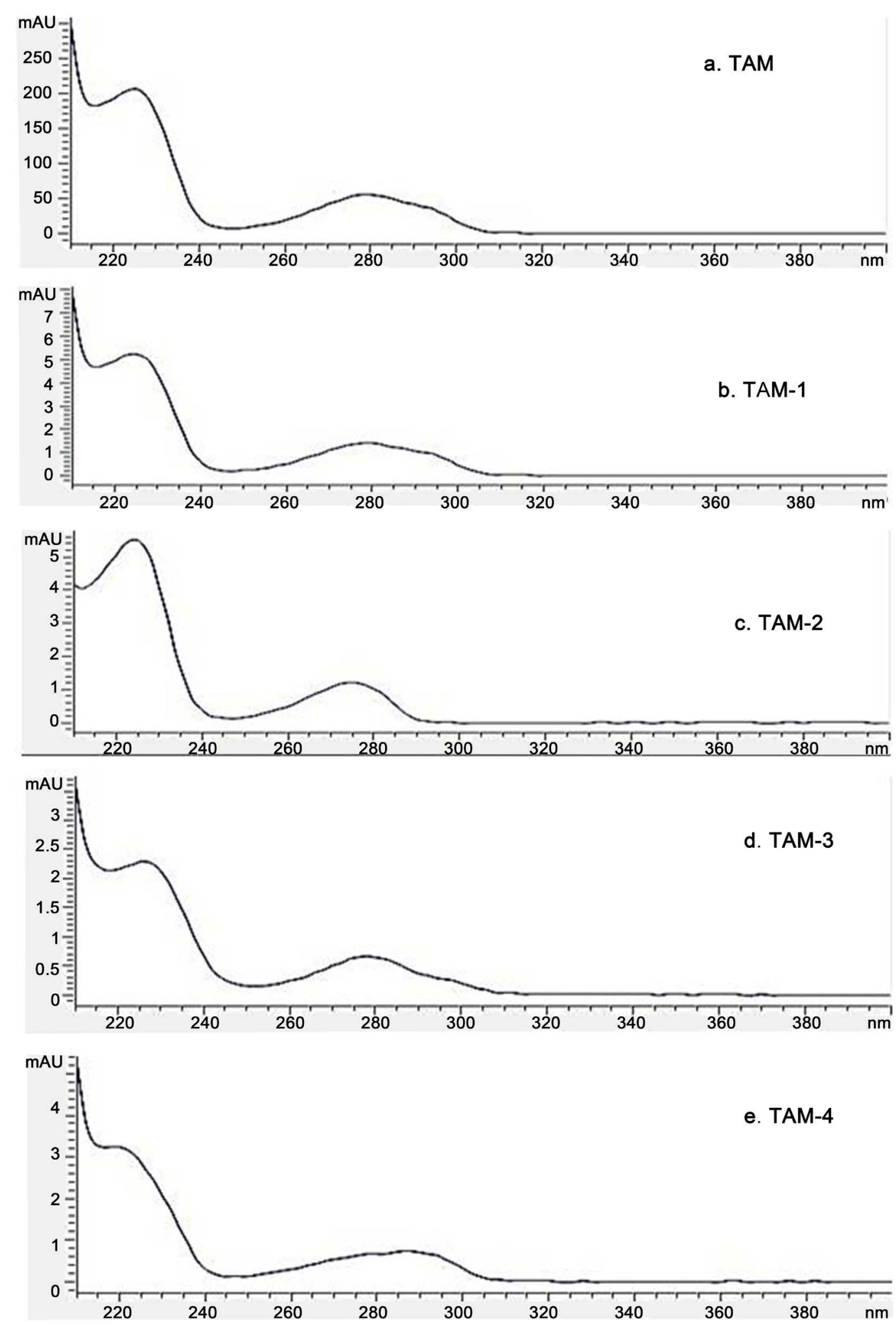

(B)

Figure 6. (A) UV spectrum of SOL and their impurities (a. SOL; b. SOL-1; c. SOL-2; d. SOL-3); (B) UV Spectrum of TAM and their impurities (a. TAM; b. TAM -1; c. TAM -2; d. TAM -3; e. TAM-4). 
ties were established and reported in Table 3.

\subsubsection{Accuracy}

The percentage recovery was ranged from $99.8 \%$ to $100.1 \%$ for SOL and from $99.8 \%$ to $100.2 \%$ for TAM in the assay analysis and the results are presented in Table 6 . The percentage recovery of impurities varied from $98.8 \%$ to $101.8 \%$ in the analysis of impurities. The \% recovery values for SOL and TAM and their impurities are presented in Table 4.

\subsubsection{Precision}

The assay results of SOL and TAM during the assay method repeatability study was showed, less than $2.0 \%$ RSD of SOL and TAM respectively. Similarly the results of all the impurities (SOL-1, SOL-2, SOL-3, TAM-1, TAM-2, TAM-3 and TAM-4) in related substance method repeatability study was showed less than $15 \%$ RSD for each individual impurity. Data of repeat experiment was showed less than 0.3\% RSD for Assay and less than $4.5 \%$ RSD for impurities. These results are conforming good precision of the method. The \% RSD values are presented in Table 3.

\subsubsection{Robustness}

In all the deliberate varied chromatographic conditions like flow rate $\left(-0.2 \mathrm{~mL} \cdot \mathrm{min}^{-1}\right.$ and $+0.2 \mathrm{~mL} \cdot \mathrm{min}^{-1}$ of $\left.0.9 \mathrm{~mL} \cdot \mathrm{min}^{-1}\right)$, column temperature $\left( \pm 5^{\circ} \mathrm{C}\right.$ of $\left.30^{\circ} \mathrm{C}\right)$, and $\mathrm{pH}$ of mobile phase buffer $( \pm 0.1 \mathrm{pH} 6.6)$, all analytes were adequately resolved and elution orders remained unchanged. The resolution between all pair compounds was greater than 2.0 and tailing factor for SOL and TAM and their impurities was less than 1.5. The variability in the estimation of SOL and TAM impurities was within $\pm 10 \%$.

\section{Conclusion}

The rapid reproducible gradient RP-HPLC method developed for quantitative analysis of SOL and TAM and related substances in pharmaceutical dosage form is precise, accurate, linear, robust and specific. Satisfactory results were obtained from validation of the method. The method is stability-indicating and can be used for routine analysis of production samples to check the stability [26] of SOL and TAM in combined dosage form.

\section{References}

[1] Astellas Pharma Europe BV (2014) Vesomni 6 mg/0.4 mg Modified-Release Tablets. Public Assessment Report of the Medicines Evaluation Board in the Netherlands, Solifenacin Succinate/Tamsulosin Hydrochloride, Vesomni SPC, The Netherlands.

https://www.medicines.org.uk/emc/medicine/28535

[2] Lim, K.T., Kim, Y.T., Lee, T.Y. and Park, S.Y. (2011) Effects of Tamsulosin, Solifenacin, and Combination Therapy for the Treatment of Ureteral Stent Related Discomforts. Korean Journal of Urology, 52, 485-488. http://dx.doi.org/10.4111/kju.2011.52.7.485

[3] Nazir, J., Heemstra, L., van Engen, A., Hakimi, Z. and Ivanescu, C. (2015) Cost-Effectiveness of a Fixed-Dose Combination of Solifenacin and Oral Controlled Adsorption System 
Formulation of Tamsulosin in Men with Lower Urinary Tract Symptoms Associated with Benign Prostatic Hyperplasia. BioMed Central, 15, 41.

[4] Solifenacin Succinate API Monograph EP 8.6.

[5] Tamsulosin Hydrochloride API Monograph USP-38 NF33 S2.

[6] Tamsulosin Hydrochloride API Monograph EP 8.0.

[7] Tamsulosin Hydrochloride Capsules Monograph USP-38 NF33 S2.

[8] Yanagihara, T., Aoki, T., Soeishi, Y., Iwatsubo, T. and Kamimura, H. (2007) Determination of Solifenacin Succinate, a Novel Muscarinic Receptor Antagonist, and Its Major Metabolite in Rat Plasma by Semi-Micro High Performance Liquid Chromatography. Journal of Chromatography B, 859, 241-245. http://dx.doi.org/10.1016/j.jchromb.2007.10.005

[9] Rami Reddy, B.V., Srinivasa Reddy, B., Raman, N.V.V.S.S., Subhash Reddy, K. and Rambabu, C.(2012) Development and Validation of a Specific Stability Indicating High Performance Liquid Chromatographic Methods for Related Compounds and Assay of Solifenacin Succinate. Journal of Chemistry, 2013, Article ID: 412353.

[10] Radha Krishna, S., Rao, B.M. and Someswara Rao, N. (2010) A Validated Rapid StabilityIndicating Method for the Determination of Related Substances in Solifenacin Succinate by Ultra-Fast Liquid Chromatography. Journal of Chromatographic Science, 48, 807-810. http://dx.doi.org/10.1093/chromsci/48.10.807

[11] Chandra Mohan, T., Hemalatha, B., Shainy, B., Vasundhara, G., Sandhya, S. and Ashok Kumar, A. (2014) A Rapid RP-HPLC Method Development and Validation for the Quantitative Estimation of Solifenacin Succinate in Tablets. International Journal of Pharmacy and Pharmaceutical Sciences, 6, 201-204.

[12] Shaik, R.P., Puttagunta, S.B., Bannoth, K.C. and Reddy Challa, B.S. (2014) Analytical Method Development and Validation of Solifenacin in Pharmaceutical Dosage Forms by RP-HPLC. ISRN Analytical Chemistry, 2014, Article ID: 132020.

[13] Desai, N., Hussen, S.S., Vasanthraju, S.G., Karthik, A. and Udupa, N. (2010) Development \& Validation of Stability Indicating HPLC Method for Determination of Solifenacin in Bulk Formulations. International Journal of Pharmacy and Pharmaceutical Sciences, 3, 70-74.

[14] Puttagunta, S.B., Shaik, R.P., Bannoth, C.K., Reddy Challa, B.S. and Awen, B.Z. (2014) Bioanalytical Method for Quantification of Solifenacin in Rat Plasma by LC-MS/MS and Its Application to Pharmacokinetic Study. Journal of Analytical Science and Technology, 5, 35. http://dx.doi.org/10.1186/s40543-014-0035-0

[15] Divya Teja, G., Deva Dasu, C.H., Srinivasa Babu, P. and Ravisankar, P. (2013) Quantitative Analysis of Solifenacin Succinate in Pharmaceutical Dosage Form Using UV Absorption Spectroscopy. Journal of Chemical and Pharmaceutical Sciences, 6, 195-198.

[16] Sudha, T. and Dhomane, J. (2011) A Validated RP-HPLC Method for the Determination of Impurities in Tamsulosin HCL. International Journal of Chemistry Research, 2, 29-33.

[17] Santhi Priya, M., Shanta kumari, K., Bhanu Prasad, M., Priyanka, G. and Sirisha, T. (2014) Impurity Method Development and Validation of Tamsulosin Hydrochloride by Using RPHPLC. World Journal of Pharmaceutical Research, 3, 998-1005.

[18] Basniwal, P.K., Panda, S., Jain, S. and Deepti, J. (2012) Stability-indicating HPLC Assay Method and Degradation Profile of Tamsulosin. American-Eurasian Journal of Scientific Research, 7, 193-198.

[19] Dunn, C.J., Matheson, A. and Faulds, D.M. (2002) Tamsulosin: A Review of Its Pharmacology and Therapeutic Efficacy in the Management of Lower Urinary Tract Symptoms. Drugs Aging, 19, 135-161. http://dx.doi.org/10.2165/00002512-200219020-00004 
[20] Ramakrishna, N.V., Vishwottam, K.N., Manoj, S., Koteshwara, M., Wishu, S. and Varma, D.P. (2005) Rapid, Simple and Highly Sensitive LC-ESI-MS/MS Method for the Quantification of Tamsulosin in Human Plasma. Biomedical Chromatography, 19, 709-719. http://dx.doi.org/10.1002/bmc.498

[21] Vijaya Saradhi, S., Meherjaha, S.K., Prithvi Prasad, Y., Baby Sirisha, P. and Bala Sekaran, C. (2013) RP-HPLC Method for the Estimation of Tamsulosin in Bulk and Capsules. International Journal of Pharmacy and Pharmaceutical Sciences, 5, 342-345.

[22] Vijaya Saradhi, S., Meherjaha, S.K., Jyothsna, N., Priyanka, A., Baby Sirisha, P., Ramakrishna, C. and Bala Sekaran, C. (2012) Novel Spectroscopic Methods for the Determination of Tamsulosin in Bulk and Capsules. Journal of Pharmaceutical Sciences and Research, 4, 1958-1963.

[23] Siva Rama Krishna, G.V., Janardhan, M. and Rasool, S.K. (2012) Development and Validation of Stability-Indicating RP-HPLC Method for Estimation of Tamsulosin HCL Pellets. International Journal of Pharmaceutical Invention, 2, 51-60.

[24] Israel, D.S., Krishnachaitanya, K. and Gowri Sankar, D. (2013) RP-HPLC Method for the Estimation of Tamsulosin and Solifenacin in Bulk and Its Dosage Forms. International Journal of Pharmaceutical Sciences and Research, 4, 4343-4350.

[25] International Committee on Harmonization (ICH) (2005) Validation of Analytical Procedures: Text and Methodology Q2 (R1). IFPMA, Geneva.

[26] International Committee on Harmonization (ICH) (2003) Stability Testing of New Drug Substances and Products Q1A (R2). IFPMA, Geneva.

Submit or recommend next manuscript to SCIRP and we will provide best service for you:

Accepting pre-submission inquiries through Email, Facebook, LinkedIn, Twitter, etc.

A wide selection of journals (inclusive of 9 subjects, more than 200 journals)

Providing 24-hour high-quality service

User-friendly online submission system

Fair and swift peer-review system

Efficient typesetting and proofreading procedure

Display of the result of downloads and visits, as well as the number of cited articles

Maximum dissemination of your research work

Submit your manuscript at: http://papersubmission.scirp.org/

Or contact ajac@scirp.org 